\title{
A review: nutrition quality and processing of Malaysian strawberries
}

\author{
1,*'Rosnah, S., ${ }^{2}$ Hamzah, H.Z., ${ }^{3}$ Shuso, K., ${ }^{4}$ Yasunaga, E. and ${ }^{5}$ Mahat, F. \\ ${ }^{1}$ Department of Process and Food Engineering, Faculty of Engineering, Universiti Putra Malaysia, 43400 \\ UPM Serdang, Selangor, Malaysia \\ ${ }^{2}$ Department of Economics, Faculty of Economics and Management, Universiti Putra Malaysia, 43400 \\ UPM Serdang, Selangor, Malaysia \\ ${ }^{3}$ Laboratory of Agricultural and Food Process Engineering, Graduate School of Agricultural Science, \\ Hokkaido University, Kita 8, Nishi 5, Kita-ku, Sapporo, Hokkaido, 060-0808 Japan. \\ ${ }^{4}$ Graduate School of Agricultural and Life Sciences, The University of Tokyo 1-Chome-1-1 Yayoi, Bunkyo \\ City, Tokyo 113-0032, Japan \\ ${ }^{5}$ Department of Management, Faculty of Economics and Management, Universiti Putra Malaysia, 43400 \\ UPM Serdang, Selangor, Malaysia
}

\section{Article history:}

Received: 15 August 2019

Received in revised form: 6

November 2019

Accepted: 11 December

2019

Available Online: 10

February 2020

Keywords:

Strawberry,

Nutritional,

Post-harvest,

Processing

DOI:

https://doi.org/10.26656/fr.2017.4(S1).S10

\begin{abstract}
Malaysian strawberries planted in the Cameron Highlands region are mostly done by small-scale farmers and often face post-harvest losses due to the highly perishable nature of strawberries and lack of information on available processing technologies. This review intended to give an overview of the nutritional quality of strawberries, post-harvest factors that contribute to quality decrement and processing practices done to reduce losses as well as increase the shelf-life of strawberries. Literature comparison between Malaysia and other countries was done on available prior studies and written reports. The review revealed that strawberries are rich in anthocyanin (which contributes to its red colour and flavour) and vitamin $\mathrm{C}$, high in moisture content (up to $92 \%$ at ripening stage), have an acidic pH (ranging from 3.39 to 3.8 upon ripening) and sweet in taste (glucose, fructose and sucrose are the major soluble sugars available in strawberries). Several factors contributed to strawberry fruits losses and deterioration including the effect of improper handling, storage condition and pathogen bacteria attack. Drying and pasteurisation processes are the most common practices done in strawberry processing due to the effectiveness of the treatments in extending their shelf-life.
\end{abstract}

\section{Introduction}

Strawberries or scientifically known as Fragaria $\times$ ananassa are popular among consumers due to their unique taste, vibrant colour and appealing visual. Strawberries are non-climacteric fruits (Bhat and Stamminger, 2014) belonging to the "Rosaceae" family which have over six hundred varieties planted (Zeb et al., 2015). Strawberries can be planted either in seasonal or tropical climate areas. However, differences in climate do affect the overall quality and taste of strawberries. Cultivation and growing conditions, genotype and cultivars contribute to the diversity of the nutritional composition of strawberries which then relatively affects its flavour (Aaby et al., 2012).

Strawberries in Malaysia are planted in the highland regions with Cameron Highlands, one of the famous strawberries planting areas. Cameron Highlands is well known as an agro-tourism area in Malaysia, in which $90.18 \%$ of its land is forested area and $8.32 \%$ are agriculture land (include plantation of vegetables, tea and strawberries) (Leh et al., 2017). The environmental temperature of Cameron Highlands which is less than $25^{\circ} \mathrm{C}$ provides an optimum condition for strawberries cultivation (Eisakhani and Malakahmad, 2009). Strawberries are known as an iconic crop of Cameron Highlands and chosen as a product in the "one district, one industry" campaign by the Malaysian government. Camarosa and Camaroga cvs. cultivar are among the popular varieties planted in Cameron Highlands (Isma et al., 2012) alongside the Festival, Camariosa, Montere, Sweet sensation, Winter star and Albion varieties in which most of these hybrids were bought from California, the United States of America. The production 
of strawberries in Malaysia is rather low due to the country's tropical climate with humidity in the planting area of approximately more than $90 \%$. Rainy weather also contributes to low pollen germination as the bees' pollination activities are limited (Isma et al., 2012). Strawberries in Malaysia are best enjoyed fresh during the period between May till August as the weather condition at that period is ideal for the growth of strawberries with less rainfall (Ramachandran et al., 2015).

Cultivation of strawberries in Cameron Highlands, Malaysia mostly uses hydroponic methods planted in greenhouses to ease the control of an ideal environment condition for strawberries growth. Temperature and humidity of the greenhouse are often maintained at $20^{\circ} \mathrm{C}$ and $70 \%$ humidity (Ramachandran et al., 2015). Fresh strawberries have a short life; thus, the unsold ones are often utilised into other products such as jams, pickles, biscuits and confectioneries. The utilisation of strawberry into strawberry-based products in Malaysia is still minimal as it is done by small and medium scale manufacturers and processors. Thus, the factors contributing to the losses of post-harvest strawberries, the post-harvest practices to overcome the losses and processing of strawberries into valuable products are intended to be discussed in this present review.

\section{Physical, chemical and nutritional characteristics}

Strawberries are characterised as herbaceous plants with fibrous roots and basal leaves that arise from the crown (Kuchi and Sharavani, 2019). Figure 1 shows the cross-section of a strawberry fruit which consists of the flesh (pulp) with a lighter colour at the core centre, either light pink or white in colour, and the outer part of the fruit is covered with achenes (or seeds).

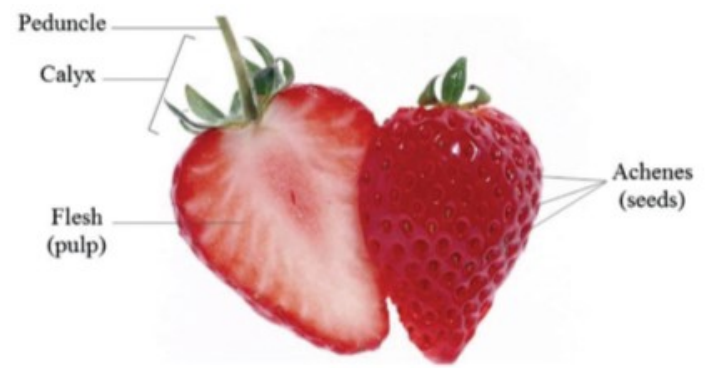

Figure 1. Cross section of strawberry fruit (Fragaria $x$ ananassa). Adapted from Muthukumaran et al. (2017)

The chemical composition of strawberries changes during the ripening process. The total soluble solids (TSS) and $\mathrm{pH}$ of strawberries increase from $6.6 \%$ to $9.0 \%$ and from $\mathrm{pH} 3.39$ to $\mathrm{pH} 3.80$ respectively, but the moisture content (ranging from $91.9 \pm 0.4 \%$ to $92.5 \pm 0.8 \%$ ) remains insignificantly different during the ripening stages 1 to 6 (Ornelas-Pas et al., 2013). Glucose, fructose and sucrose are the major soluble sugars in strawberries in which glucose (1.4 to $3.1 \%$ fresh weight) and fructose (1.7 to $3.5 \%$ fresh weight) increase during the development of the fruit whereas sucrose increases during the maturity process (Kuchi and Sharavani, 2019). Citrate is the main organic acid in strawberries which relatively affects the overall flavour and taste of the strawberries. Asparagine, glutamine and alanine also contribute to the sensory sensation of strawberries. Anthocyanins with an approximate content of 0.5 to $1.5 \mathrm{mg} / \mathrm{g}$ fruit weight are the major component in strawberries which contributes to their colour and taste, whereas ascorbic acid $(0.3$ to $1.2 \mathrm{mg} / \mathrm{g}$ fruit weight) is the main amino acids with nutritional benefits. Ascorbic acid or the vitamin $\mathrm{C}$ content in strawberries is higher than oranges with added vitamin $\mathrm{K}$, vitamin $\mathrm{B} 5$, vitamin B6, manganese, magnesium, copper, potassium and omega 3 fatty acid (Hakkinen and Torronen, 2000). Strawberries are believed to have an anti-cancer effect due to the high nutritional contents of folates, minerals, vitamins and phenolic constituents (Giampieri et al., 2013)

\section{Postharvest factors affecting strawberry fruits quality}

Fruits will undergo a postharvest system after harvesting before they reach the end consumer and prevent losses. From 2011 to 2013, the postharvest losses of fruits in Malaysia have increased each year from $1,622,603$ to $1,658,332$ to $1,765,828$ metric tonnes in which attitudes and infrastructure are the two main causes identified (Tengku Mohamed, 2017). According to Osman (2011), there are several factors that contribute to the quality of fruits during the postharvest process which include temperature, chilling injuries (CI), green ripening, loss of texture, browning of peel and pulp, relative humidity, loss of weight, shrinkage of fruit peel, peeling difficulty disorder (PDD), gases composition of storage atmosphere, mechanical damage and pathogen (Osman, 2011).

Strawberries are highly perishable fruits in which improper handling during postharvest may affect their overall quality. Hailu (2005) stated that the production of fresh products is complex due to their perish-ability and mass quantity, highlighting a need to be managed with care during the postharvest period. The ideal harvesting period of strawberries is 3 to 4 months after planting in which bruising of the fruit could Literature happen as ripening strawberries are soft in nature (Kuchi and Sharavani, 2019). The bruises may be due to the mechanical impact during picking, storage and transportation. 
Temperature, gas composition of storage atmosphere and relative humidity are among the main contributing factors in retaining strawberry fruit quality, especially during storage. Fresh strawberries are recommended to be cooled to a temperature near $0^{\circ} \mathrm{C}$ within 1 hour after harvesting to preserve their freshness. Storage condition plays an important role to maintain strawberries' quality after harvesting. Modified atmosphere (MA) storage condition is able to retain the freshness of strawberries during post-harvest. Alterations of carbon dioxide $\left(\mathrm{CO}_{2}\right)$ and oxygen $\left(\mathrm{O}_{2}\right)$ level during storage of $10 \% \mathrm{CO}_{2}$ and $11 \% \quad \mathrm{O}_{2}$ efficiently reduce the decay rate of fresh strawberries and maintain their quality (Almenar et al, 2006; Riad and Breacht, 2005).

Pathogen is another factor that affects the quality of strawberries, either fresh or processed into products. Pathogens are relatively affected by environmental and storage conditions. Post-harvest losses of strawberries often happened due to bacterial infection from the effect of environmental and storage conditions (Salami et al., 2010). Strawberries are strongly affected by diseases and pests, especially with unfavourable weather conditions throughout the vegetation season and harvest (Sojka et al., 2015); thus, strawberries are processed into other valuable products to increase their shelf-life. Figure 2 shows the condition of strawberry fruits after harvesting which have been affected by moulds due to improper handling and storage conditions during postharvest. Strawberries in Malaysia are mainly managed by smallscale farmers and marketed locally. Small-scale farmers often face multiple problems during the pre and postharvest periods due to insects, diseases, weeds and droughts. Cameron Highlands is well known as strawberries plantation area in Malaysia facing the issues mentioned due to its geographical factors which are sensitive towards any ecosystem changes (Rahim et al., 2016). Besides, the trend of the strawberry market at Cameron Highlands depends on the visitors where during the holiday periods in Malaysia, the strawberries are high in demand while during the regular working days, farmers experience losses as the strawberries are over-ripening which consequently leads to dumping.

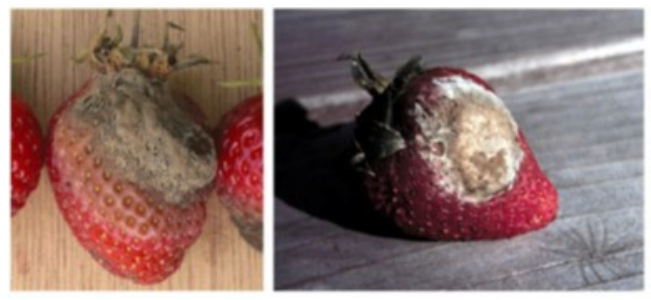

Figure 2. Strawberry infected by Botrytis cinera disease. Adapted from Salami et al. (2010)

\section{Postharvest processing and products}

\subsection{Sanitisation of postharvest strawberries}

Pesticides are often used by farmers to increase productivity and product yields. However, such practices cause later effects of bio-accumulation of pesticides through the food chain (Kin and Huat, 2010); thus, the sanitisation process is needed upon harvesting to get rid of any pesticides residue. Contamination of fresh strawberries may happen due to insects, soil, water or improper handling, either during the pre-harvest or postharvest stages, thus sanitisation is a crucial first approach for inactive spoilage bacteria to preserve the freshness of products (Nicolau-Lapena et al., 2019). A prior study by Kin and Huat (2010) on sanitisation of strawberry fruits collected at the Malaysian Agricultural Research and Development Institute (MARDI), Cameron Highlands with different sanitising solutions of acetic acid, sodium carbonate, sodium chloride and solely tap water showed that acidic solutions of 5 to $10 \%$ acetic acid in tap water removed around 44 to $70 \%$ pesticide residues in strawberries after soaking for 10 to 30 minutes and dried overnight. Later in 2019, Nicolau-Lapena et al. (2019) proved that acidic solution was able to disinfect spoilage microorganism in fresh strawberries, whereas washing with only water will cause cross-contamination and increase the microbial load in fresh strawberries. Fresh strawberries inoculated with Listeria Innocua at concentrations of peracetic acid of 20 to $80 \mathrm{ppm}$ in tap water experienced up to $4 \log$ reduction without significant alterations of the physicochemical and antioxidant properties of strawberries (Nicolau-Lapena et al., 2019).

\subsection{Storage of fresh strawberries}

Storage of fresh strawberries is crucial to maintain their freshness and acceptability before they meet the end consumers for direct consumption or for further processing into products. Fresh strawberry fruits need to be stored at lower temperatures to retard microbial growth and to preserve the nutritional contents. Octavia and Choo (2017) studied the effect of storage on the quality of fresh Camarosa strawberries from Cameron Highlands refrigerated at $4^{\circ} \mathrm{C}$ which resulted in the degradation of nutritional and bioactive compounds due to the effect of storage time. $88.1 \%, 55.5 \%$ and $93.2 \%$ of anthocyanin, ascorbic acid and folate contents were lost after 6 days of storage, thus it was recommended that fresh strawberries be consumed within 2 days for the best quality and nutritional contents.

For a longer storage period of Malaysian strawberries, other factors than temperature need to be take into consideration as mentioned earlier (Section 3); gas composition, atmosphere and relative humidity are 
crucial in controlling the quality of freshly harvested strawberries. Jadhav and Gurav (2018) found that the Sweet Charlie variety of strawberries (originated from India) stored at a cold storage of $4^{\circ} \mathrm{C}$ at $95 \%$ relative humidity (RH) had greater quality than strawberries stored at room temperature (RT) with a longer shelf-life of 4 days compared to 2 days of RT storage. Controlled $\mathrm{RH}$ showed better preservation effects on the strawberry fruits. Higher weight loss was found in RT (6.18\%) stored strawberries than cold storage $(3.10 \%)$ after 3 days of storage, with lower ascorbic acid content. The firmness of strawberries during RT storage also decreased with a higher total soluble solid content. The increase in total soluble solids during storage may be due to sugar decomposition which later contributed to microbial growth. Similarly, Yang et al. (2018) found that the total soluble solid of the Sweet Charlie variety (originated from Hubei province, China) increased as the temperature of storage increased from 15 to $35^{\circ} \mathrm{C}$ during 12 days of storage. On the $8^{\text {th }}$ day of storage, there were $11.12 \pm 1.0 \%, 28.38 \pm 2.22 \%$ and $45.88 \pm 2.63 / \%$ weight loss at storage temperatures of 15,25 and $35^{\circ} \mathrm{C}$ respectively, with greater degradations of anthocyanins and ascorbic acid content at increasing storage temperatures.

Since Malaysia has a tropical climate with higher RH which contributes to microorganism growth in strawberries, modified atmosphere storage may be implemented to extend the shelf-life of fresh strawberries. The Charlotte variety of strawberries (originated from Geongsang province, Republic of Korea) stored in an acrylic chamber $(90 \times 60 \times 60 \mathrm{~cm})$ at $4^{\circ} \mathrm{C}$ for 10 days were injected with $30 \mathrm{kPa} \mathrm{CO} 2$ for 1 and $3 \mathrm{hr} ; 50 \mathrm{kPa}$ for 1 and $3 \mathrm{hr} ; 70 \mathrm{kPa}$ for for 1 and $3 \mathrm{hr}$. Colour properties of lightness $\left(\mathrm{L}^{*}\right)$ and redness $\left(\mathrm{a}^{*}\right)$ did not significantly change after injected with $\mathrm{CO}_{2}$ at all treatment conditions. Injection of higher concentrations of $\mathrm{CO}_{2}$ from $30 \mathrm{kPa}$ to $70 \mathrm{kPa}$ increased the firmness of strawberries compared to the controlled ones with increasing $\mathrm{pH}$ value from 3.35 to an average of 3.76 after 10 days of storage. Total anthocyanin content (TAC) decreased after $\mathrm{CO}_{2}$ treatment for all conditions and increased in value during storage but was lower than the controlled sample which may be due to the delayed accumulation of TAC. Meanwhile, the total phenolic content (TPC) increased during storage of all samples with the highest increment of TPC shown in the controlled untreated sample. Despite lower bioactive values during storage, the microbial load of the modified atmosphere storage and the total aerobic bacteria decreased after $\mathrm{CO}_{2}$ treatment at all treatment conditions with lower counts at higher concentrations of $\mathrm{CO}_{2}, 70$ $\mathrm{kPa}$ throughout storage of 10 days. Thus, lower storage temperature, with proper gas composition and relative humidity can positively improve the freshness of strawberry fruits intended for fresh consumption.

\subsection{Postharvest processing}

Preservation is crucial for fresh strawberries, either intended for fresh consumption or further processing as fresh strawberries have a short shelf life and easily spoiled. Freezing is one of the most used physical treatments on strawberries to preserve their nutritional quality for later use and processing. Freezing is regarded as a conventional physical treatment in which the water content of food is reduced below its freezing point and experiences a state of change to form ice crystals (Fellow, 2002). The Festival variety of strawberries packed in a polyethylene bag and freeze at $-27^{\circ} \mathrm{C}$ using a commercial freezer (Arcelik, 2572D) were able to retain ascorbic acid loss below $50 \%$ up to 13 weeks of storage ( $42 \%$ loss) from the initial value of $38 \mathrm{mg} / 100 \mathrm{~g}$, with minimal decrement of colour properties of $\mathrm{L}^{*}$ and $\mathrm{a}^{*}$ and unnoticeable colour changes $(\Delta \mathrm{E}<1.5)$. Nurzahida, Sakinah and Abdullah (2010) studied the effect of freezing as one of the preservation techniques on the ice crystal formation of local strawberries from Cameron Highlands. Based on the study, frozen strawberries were able to preserve their appearance, colour and texture with the moisture content of fresh and dried strawberries at 89.6 and $10.8 \%$ respectively after the blast freezing process at $-40^{\circ} \mathrm{C}$ for 120 minutes and at a constant pressure of 0.1 Torr for 72 hours.

Table 1 summarises the recent research done on the preservation of fresh strawberries planted in other regions and countries. Treatments with gamma radiation, pulsed light and edible coating have been used to preserve the strawberries, whereas such practices are still uncommon for fresh strawberries preservation in Malaysia. The Camarosa variety is one of the most planted varieties in Malaysia. Based on Table 1, Camarosa strawberries from Aizawl, India preserved by coating with edible oil before storage and refrigerated at $4^{\circ} \mathrm{C}$ showed that the sensory and colour properties were not relatively affected with better retention of ascorbic acid and anthocyanins content throughout 16 days of storage (Hazarika et al. 2019). The similar variety from Spain was used in a study by Avalos-Llano et al. (2018) on the effect of pulsed light on strawberries quality attributes. Before undergoing treatment with pulsed light, freshly harvested Camarosa strawberries were sanitised by immersing into $200 \mu \mathrm{L} / \mathrm{L}$ sodium hypochlorite for 1 min and rinsing with tap water to inhibit fungal occurrence for a longer time. Pulsed light at doses of 4, 8,12 and $16 \mathrm{~J} / \mathrm{cm}^{2}$ reduced browning in strawberries due to enzymatic activity. However, redness of strawberries treated at $16 \mathrm{~J} / \mathrm{cm}^{2}$ showed greater decrement which may 
Table 1. Physical treatments on fresh strawberries

\begin{tabular}{|c|c|c|c|}
\hline $\begin{array}{c}\text { Strawberry } \\
\text { variety/ origin }\end{array}$ & $\begin{array}{c}\text { Physical treatment and } \\
\text { parameter }\end{array}$ & Quality assessment & References \\
\hline $\begin{array}{l}\text { Camarosa from } \\
\text { Aizawl, India }\end{array}$ & $\begin{array}{l}\text { Edible coating: } \\
100 \% \text { coconut oil } \\
\text { Strawberry fruit firstly } \\
\text { dipped into } 2 \% \text { chitosan, } 1 \% \\
\text { acetic acid solution and left } \\
\text { for } 12 \mathrm{hr} \text { for bubble removal } \\
\text { before dipped into coating } \\
\text { solution, glycerol then } \\
\text { added as a plasticiser. }\end{array}$ & $\begin{array}{l}\text { Coconut oil edible coated strawberry lowest in } \\
\text { physiological weight loss }(17.57 \%) \text {, greater texture } \\
(3.85 \mathrm{~N}) \text { after } 16 \text { days refrigerated storage } 4^{\circ} \mathrm{C} \text { compared to } \\
\text { uncoated }(25.27 \%, 2.58 \mathrm{~N}) \text { with excellent retention of } \\
\text { ascorbic acid }(65.74 \mathrm{mg} / 100 \mathrm{~mL} \text { juice) and anthocyanin } \\
\text { content }(33.38 \%) . \\
\text { Overall acceptability of appearance, flavour, taste shown } \\
\text { coconut oil coating scored the highest likeability. }\end{array}$ & $\begin{array}{c}\text { Hazarika et } \\
\text { al. (2019) }\end{array}$ \\
\hline $\begin{array}{l}\text { Camino from } \\
\text { Brazil }\end{array}$ & $\begin{array}{l}\text { Gamma radiation: } \\
1.0,2.0,3.0 \text { and } 4.0 \mathrm{kGy} \text { at } \\
8 \pm 1^{\circ} \mathrm{C} \text { with Cobalt } 60 \\
\text { source Category II } \\
\text { Panoramic Multipurpose } \\
\text { Radiator (MDS Nordion, } \\
\text { Canada) }\end{array}$ & $\begin{array}{l}\text { No significant change of firmness at all treatment } \\
\text { condition. } \\
\text { Significant loss ( } \mathrm{p}<0.05) \text { in strawberry weight at lower } \\
\text { dose, shorter storage time, with no significant colour } \\
\text { changes after treatments (at all dosage induce). } \\
\text { Ascorbic acid at } 3.0 \mathrm{kGy} \text { retains higher value } \\
(65.71 \pm 11.76 \mathrm{mg} / 100 \mathrm{~g} \text { fruit) compared to other doses } \\
\text { after treatment. }\end{array}$ & $\begin{array}{l}\text { Filho et al. } \\
\text { (2018) }\end{array}$ \\
\hline $\begin{array}{c}\text { Camarosa from } \\
\text { Spain }\end{array}$ & $\begin{array}{l}\text { Pulsed light: } \\
\text { Doses of } 4,8,12 \text { and } 16 \mathrm{~J} / \\
\mathrm{cm}^{2} \text { per side using pulsed } \\
\text { UV system Model } \\
\text { XeMaticA-2 L ( } 360^{\circ} \text { sample } \\
\text { illumination)(SteriBeam } \\
\text { System GmbH, Kehl, } \\
\text { Germany) }\end{array}$ & $\begin{array}{l}\text { No sign of browning shown at all treatment condition after } \\
10 \text { days. } \\
\text { Redness }\left(\mathrm{a}^{*}\right) \text { decrease at lower dosage during storage but } \\
\text { more prominent decrement shown at } 16 \mathrm{~J} / \mathrm{cm}^{2} \text {. } \\
\text { Pulsed light able to retain firmness of strawberries after } \\
\text { treatment at all dosage. } \\
\text { Higher dosage affects the antioxidant, ascorbic acid and } \\
\text { phenolic content during storage at } 5^{\circ} \mathrm{C} \text { for } 14 \text { days in } \\
\text { darkness but still maintain higher value compared to } \\
\text { untreated sample. }\end{array}$ & $\begin{array}{c}\text { Avalos- } \\
\text { Llano et al. } \\
\text { (2018) }\end{array}$ \\
\hline
\end{tabular}

be due to the anthocyanin colour pigment degradation. Higher dose induced relatively affected the anthocyanins and ascorbic acid content in fresh strawberries; however, such loss was still lower than the untreated sample. An alternative non-thermal treatment used for strawberries was gamma radiation which also showed promising results of extending the strawberries' shelf-life without severely affecting the nutritional and sensory properties (Filho et al. 2018). Pulsed light treatment implies short time pulse at wavelength between 100 to $1100 \mathrm{~nm}$, whereas gamma radiation is an ionising radiation in which both cause DNA damage of microorganisms and relatively kill them as they are unable to replicate.

Utilisation of fresh strawberries into other products is one of the best methods to improve their marketability as well as increase the strawberries' shelf-life. Dried strawberries, jams, juices and beverages are the most popular strawberry-based products in Malaysia. Among the processing techniques, processing using heat is the most commonly used by manufacturers, either in Malaysia or worldwide due to its widely known effectiveness in microbial inactivation and shelf-life extension. However, due to massive degradation of nutritional and antioxidant quality, researchers had shifted their interest towards alternative physical treatments such as pulsed light, sonication and high- pressure processing (HPP). Table 2 summarises, in brief, some of the physical treatments used in the processing of dried strawberries.

Drying is one of the common physical treatments to preserve the quality of food and not limited to only fruits. Drying is done to reduce the water content in food to inhibit the growth of microorganisms for the later purposes of marketing, storage and processing (Misha et al., 2013). Dried strawberry products are a healthier choice of snacking as the basic nutritional content is better preserved compared to processed junk food (Kowalska et al., 2017). Based on Table 2, De Brujin and Börques (2014) found that a combined treatment of osmotic dehydration and vacuum microwave drying was able to remove water efficiently with improved firmness and better colour and nutritional qualities compared to conventional air-drying. Later in 2017, Adak et al. (2017) studied the effect of infrared drying on the Camarosa variety from Turkey in which the colour properties and anthocyanin content of dried strawberries were well retained at air velocity of $1 \mathrm{~m} / \mathrm{s}, 200 \mathrm{~W}$ at $80^{\circ} \mathrm{C}$. Nazmer et al. (2018) then compared the quality of freeze-dried strawberries with strawberries dried with a hot-air dryer. Freeze-dried strawberries resulted in better nutritional retentions of anthocyanins, ascorbic acids, total phenolic and total antioxidant content with less 
Table 2. Processing of dried strawberries

\begin{tabular}{|c|c|c|c|c|}
\hline $\begin{array}{c}\text { Strawberry } \\
\text { variety/ origin }\end{array}$ & Product & Physical treatment and parameter & Quality assessment & References \\
\hline $\begin{array}{l}\text { San Andreas } \\
\text { (Chile) }\end{array}$ & $\begin{array}{c}\text { Dried } \\
\text { strawberries }\end{array}$ & $\begin{array}{l}\text { Air drying : } \\
70^{\circ} \mathrm{C}, 10 \text { hours in Proctor- } 0.62 \text { tray dyer } \\
\text { (Proctor and Schwartz Corp, } \\
\text { Philadelphia, USA) } \\
\text { Vacuum microwave drying : } \\
50{ }^{\circ} \mathrm{C} \text { and air velocity } 1.0 \mathrm{~m} / \mathrm{s} \text { in the } \\
\text { mechanical heating oven (Binder FD 53, } \\
\text { Tuttlingen, Germany) and air heating } \\
\text { with electrical resistance of } 1200 \mathrm{~W} \text { with } \\
3 \text { trays as closed circuit } \\
\text { Osmotic dehydration-vacuum } \\
\text { microwave drying: } \\
70 \text { mm Hg absolute pressure, } 10 \text { min of } \\
\text { vacuum pulse for } 4 \text { hr followed with } \\
\text { mixed into } 60 \% \text { sucrose solution shaken } \\
\text { at } 140 \text { rpm (orbital shaker, Ilshin Lab Co. } \\
\text { Ltd, South Korea) }\end{array}$ & $\begin{array}{l}\text { Osmotic dehydration-vacuum } \\
\text { microwave drying was able to } \\
\text { create the highest water flux } \\
\text { out of product with improved } \\
\text { mechanical resistance, slight } \\
\text { colour loss and acceptable } \\
\text { rehydration performance. }\end{array}$ & $\begin{array}{c}\text { De Brujin and } \\
\text { Bórquez (2014) }\end{array}$ \\
\hline $\begin{array}{l}\text { Camarosa } \\
\text { (Turkey) }\end{array}$ & $\begin{array}{c}\text { Dried } \\
\text { strawberry }\end{array}$ & $\begin{array}{l}\text { Infrared drying: } \\
\text { Power } 200-300 \mathrm{~W}, 60-100^{\circ} \mathrm{C} \text { and air } \\
\text { velocity } 1-1.5 \mathrm{~m} / \mathrm{s} \text { with automatic } \\
\text { drying system (Zenittel Automation } \\
\text { Technology System, Turkey) }\end{array}$ & $\begin{array}{l}\text { Air velocity } 1 \mathrm{~m} / \mathrm{s} \text { at } 200 \mathrm{~W} \text { of } \\
\mathrm{T} 80^{\circ} \mathrm{C} \text { yield greater colour } \\
\text { properties } \mathrm{L}^{*}, \mathrm{a}^{*}, \mathrm{~b}^{*}, \text { chroma, } \\
\text { hue angle and colour difference } \\
(\Delta \mathrm{E}<1.5) \text { (less noticeable) with } \\
\text { the highest content of } \\
\text { anthocyanins. }\end{array}$ & $\begin{array}{l}\text { Adak et al. } \\
\text { (2017) }\end{array}$ \\
\hline $\begin{array}{l}\text { From Maule } \\
\text { (Chile) }\end{array}$ & $\begin{array}{c}\text { Dried } \\
\text { strawberry }\end{array}$ & $\begin{array}{l}\text { Freeze dry: } \\
-20^{\circ} \mathrm{C}, 0.5 \mathrm{mHg} \text { absolute pressure for } 24 \\
\text { hr using Vacudyne Pilot Freeze Dier } \\
\text { (Vacudyne Inc., Chicago, Heights, } \\
\text { USA) } \\
\text { Hot-air drying: } \\
\text { Pilot air dryer (Wenger Drying } \\
\text { Technology, Inc., Sabetha, KS, USA) at } \\
\text { parallel airflow } 70^{\circ} \mathrm{C} \text { and } 0.76 \mathrm{~m} / \mathrm{s} \\
\text { velocity for } 16 \mathrm{hr}\end{array}$ & $\begin{array}{l}\text { Better anthocyanin, total } \\
\text { phenolic, ascorbic acid and } \\
\text { total antioxidant better retain } \\
\text { after freeze-dried. Minimal } \\
\text { colour changes observed after } \\
\text { both treatments. }\end{array}$ & $\begin{array}{c}\text { Nezmer et al. } \\
\text { (2018) }\end{array}$ \\
\hline
\end{tabular}

noticeable colour changes $(\Delta \mathrm{E}<1.5)$. Among the dehydration or drying techniques, freeze-drying is one of the best methods for strawberry processing as it retained most of the quality attributes (Shishehgarha et al., 2002). Kowalska et al. (2017) supported that the antioxidant content of freeze-dried strawberries resulted in wellretained vitamin $\mathrm{C}$ and polyphenolic content with acceptable sensory attributes of flavour and texture compared to the microwave-oven drying technique. The study by Shishehgarha et al. (2002) also agreed that freeze-drying below $50^{\circ} \mathrm{C}$ retained the appearance of strawberries well, with no significant difference in the colour properties. Thus, the application of the above mentioned technologies can be considered to be applied in Malaysia for processing of premium quality products with excellent nutritional values.

Besides dried strawberries, jams and spread are other popular strawberry-based products in Cameron Highlands. According to Market Insight: Malaysia (2014), strawberry jam is one of the popular flavours of jam in Malaysia alongside pineapple, grape, blackcurrant and mixed fruits jam. Jam-type spread products are mainly produced in small scale by the farmers themselves; however, no published study has described in details the processing of the products done in Cameron Highlands. The general jam processing is fruits mixed with sugar at the same ratio and cooked using thermal treatment (Naem et al., 2015) According to Holzwarth et al. (2012), strawberry jam is produced by mixing strawberry fruit, sucrose, isoglucose, and water in which the raw ingredients are heated at $90^{\circ} \mathrm{C}$ until the ${ }^{\circ} \mathrm{Brix}$ reading is approximately $63^{\circ} \mathrm{Brix}$, where the $\mathrm{pH}$ of the jam then adjusted to 2.9 by adding citric acid. The processing of strawberry jam involves heat treatment or pasteurisation process to reduce the water activities of strawberry jam which relatively promotes a longer shelf life and retain the anthocyanin colour pigments during storage at $4^{\circ} \mathrm{C}$. Naem et al. (2015) studied on the nutritional composition of commercialised strawberry jam in Malaysia and found that local strawberry jams 
provide a decent source of energy and carbohydrate with exceptionally lower fatty acids level. Besides, although the level of vitamin $\mathrm{C}$ content in jam is low due to the effect of heat processing, the strawberry jam has a higher vitamin $\mathrm{C}$ content than grape and apricot jams.

Juice processing in Malaysia still practises the conventional thermal pasteurisation as it is widely known for its efficiency in microbial inactivation and preventing deterioration of the product. However, no reported study was done in evaluating the quality of strawberry beverages and drinks in Malaysia as the market of such product is limited and manufactured in small and medium scale by the farmers to overcome the surplus of strawberries during off-peak seasons. The beverage industry in Malaysia has shown a significant increase over the past years with $15.8 \%$ contribution to the manufacturing industry in Malaysia and is normally operated by small and medium scale manufacturers (Rahim and Raman, 2015). Strawberry fruits are rich in anthocyanin pigments which contribute to the red colour of strawberry juice. Processing temperature above $80^{\circ} \mathrm{C}$ on strawberry juice relatively degrades the anthocyanin content, but the alteration of the juice $\mathrm{pH}$ to $\mathrm{pH} 2.0$ is able to withstand the changes and results in stable colour properties (Wang et al., 2015). The processing of strawberry juice can be done either using fresh or frozen strawberries. Klopotek et al. (2005) conducted a study using frozen strawberries (thawed overnight at $10^{\circ} \mathrm{C}$ ) for juice production pasteurised at $85^{\circ} \mathrm{C}$ for 5 minutes and resulted in $35 \%, 27 \%$ and $6 \%$ of vitamin $\mathrm{C}$, total phenolic content and anthocyanins loss respectively after processing. Due to the massive degradation of the nutritional content of fruit juice products after thermal pasteurisation, an alternative non-thermal technology is explored. High intensity pulsed electric field (HIPEF) treatment was used by researchers in Spain to study the effect of HIPEF on strawberry juice quality, in which the treatment was able to retain better aroma-related enzyme activities and better flavour and appearance of colour for 14 days compared to thermally pasteurised strawberry juice (Aguiló-Aguayo et al., 2009). Ripe strawberries from Auckland, New Zealand underwent high-pressure processing (HPP) for strawberry puree production and resulted in stable polyphenol oxidase (PPO) enzyme activity, and well retained antioxidant activity with no significant effect of $\mathrm{pH}$ and soluble solid of the end products (Sulaiman et al., 2016). Later in 2018, Aaby et al. (2019) compared the quality of juice and puree of the Senga Sengana variety of strawberries from Norway processed by conventional heat pasteurisation and HPP. Both HPP $\left(20^{\circ} \mathrm{C}, 1\right.$ to 3 minutes, 400 to $\left.600 \mathrm{MPa}\right)$ and thermal pasteurisation $\left(85^{\circ} \mathrm{C}, 2\right.$ minutes in boiling water) were able to extend the shelf-life of strawberry juice up to 49 days of storage compared to the untreated sample.
Despite the effectiveness in microbial inactivation, both processing techniques caused anthocyanin and ascorbic acid degradation, with browning effects more prominent in the HPP treated juice. Meanwhile, the same parameter of processing was used to treat strawberry puree and resulted in lower colour changes during 35 days storage after HPP and thermal pasteurisation, but HPP treated puree was closer to the fresh puree in sensory attributes. HPP (at 500 and $600 \mathrm{MPa}$ ) and thermally treated strawberry puree had a shelf-life of up to 46 days with heat treatment and a well-retained vitamin $\mathrm{C}$ of up to $48 \%$ of initial content compared to HPP ( 40 to $4 \%$ at 400 to $600 \mathrm{MPa}$ ). There is no implementation of non-thermal alternative juice processing in Malaysia in the juice and beverage manufacturing industry due to the lack of expertise and technology development. Besides, strawberry processing is done in small scales, causing dissemination of new technology a little harder as the market for strawberry-based products are limited and mostly focusing in the Cameron Highlands area.

\section{Conclusion}

Strawberries in Malaysia are regarded as a premium and exotic fruits as the plantation area are done on a medium-scale for local commercialisation in Cameron Highlands in the state of Pahang. The highly perishable characteristic of fresh strawberry fruits requires them to undergo proper handling process from the preharvesting, harvesting to postharvest periods until they meet the end consumers. The utilisation of strawberrybased products in Malaysia is done in small and medium scale due to the limitations of stock, technology and expertise.

\section{Conflict of Interest}

The authors declare no conflict of interest.

\section{Acknowledgements}

The authors express their gratitude to the Sumitomo Foundation Fiscal 2018 Grant for Japan-Related Research Projects for providing financial support and Universiti Putra Malaysia for the technical support to conduct this research work.

\section{References}

Aaby, K., Mazur, S., Nes, A. and Skrede, G. (2012). Phenolic compounds in strawberry (Fragaria $\mathrm{x}$ ananassa Duch.) fruits: Composition in 27 cultivars and changes during ripening. Food Chemistry, 132 (1), 86-97. https://doi.org/10.1016/ j.foodchem.2011.10.037

Aaby, K., Grimsbo, I.H., Hovda, M.B. and Rode, T.M. 
(2018). Effect of high pressure and thermal processing on shelf life and quality of strawberry puree and juice. Food Chemistry 260, 115-123. https://doi.org/10.1016/j.foodchem.2018.03.100

Adak, N., Heybeli, N. and Ertekin, C. (2017). Infrared drying of strawberry. Food Chemistry 219, 109-116. https://doi.org/10.1016/j.foodchem.2016.09.103

Almenar E., Hernández-Muńoz P., Lagarón J.M., Catalá R., and Gavara R. (2006). Controlled atmosphere storage of wild strawberry fruit (Fragaria vesca L.) Journal of Agricultural and Food Chemistry, 54(1), 86-91. https://doi.org/10.1021/jf0517492

Avalos-Llano, K.R., Martín-Belloso, O. and SolivaFortuny, R. (2018). Effect of pulsed light treatments on quality and antioxidant properties of fresh-cut strawberries. Food Chemistry, 264, 393-400. https:// doi.org/10.1016/j.foodchem.2018.05.028

Bhat R. and Stamminger R. (2014). Preserving strawberry quality by employing novel food preservation and processing techniques - Recent updates and future scope - An overview. Journal of Food Process Engineering 38(6), 536-554. https:// doi.org/10.1111/jfpe.12184

De Brujin, J. and Bórquez, R. (2014). Quality retention in strawberries dried by emergimg dehydration methods. Food Research Journal, 63(Part A), 42-48. https://doi.org/10.1016/j.foodres.2014.03.029

Fellow, P. (2000). Food Processing Technology: Principles and Practice. 2nd ed.. USA: Woodhead Publishing Limited. https://doi.org/10.1201/ NOE0849308871

Giampieri F., Alvarez-Suarez J.M. and Battino M. (2013). Strawberry and human health: Effect beyond antioxidant activity. Journal of Agricultural and Food Chemistry, 62, 3867-3876. https:// doi.org/10.1021/jf405455n

Hakkinen, S.H. and Torronen A.R. (2000). Content of flavonoids and selected phenolic acids in strawberries and Vaccinium species, influence of cultivar, cultivation site and technique. Food Research International, 33(6), 517-524. https:// doi.org/10.1016/S0963-9969(00)00086-7

Hailu, G. (2015). Extent, causes and reduction strategies of postharvest losses of fresh fruits and vegetables-A review. Journal of Biology, Agriculture and Healthcare 5(5), 49-64.

Hazarika, T.K., Lalrinfeli, Lalthanmuani, Lalchhnmawia J. and Mandal, D. (2019). Alteration of quality attributes and shelf-life in strawberry (Fragaria $x$ ananssa) fruits during storage as influence by edible coating. Indian Journal of Agricultural Sciences, 89 (1), 28-34.
Isma, A.H.A., Ahmad, S.M.Z.H.A., Zain, A.M. and Yusoff, W.A. (2012). The influence of exogenous hormone on the flowering and fruiting of strawberry (Fragara $x$ ananassa Duch). Journal of Biology, Agriculture and Healthcare, 2(4), 46-52.

Jadhav, P.B. and Gurav, N.P. (2018). Extending the storage and post-storage shelf-life of strawberry fruit cv. "Sweet Charlie" using cold storage. Research Journal of Agricultural Sciences, 9(3), 532-542.

Klopotek, Y., Otto, K. and Böhm, V. (2005). Processing strawberries to different products alters contents of vitamin $\mathrm{C}$, total phenolics, total anthocyanins, and antioxidant capacity. Journal of Agricultural and Food Chemistry, 53, 5640-5646. https:// doi.org/10.1021/jf047947v

Kin, C.M. and Huat, T.G. (2010). Headspace solid-phase microextraction for the evaluation of pesticides residue content in cucumber and strawberry after washing treatment. Food Chemistry, 123, 760-764. https://doi.org/10.1016/j.foodchem.2010.05.038

Kowalska, J., Kowalska, H., Marzec, A., Brzeziński, T., Samborska, K. and Lenart, A. (2017). Dried strawberries as a high nutritional value fruit snack. Food Science Biotechnology, 27(3), 799-807.

Kuchi, V.S. and Sharavani, C.S.R. (2019). Fruit Physiology and Postharvest Management of Strawberry. In Asao, T. (Ed.) Pre- and Post-Harvest Management Techniques for Higher Fruit Quality. IntechOpen E-book. https://doi.org/10.5772/ intechopen. 84205

Leh, O.L.H., Noor, M.H.C.M., Marzuki, M.A. and Mustafa, S.N.A.M. (2017). Social impact of agrotourism on local urban residents. Case Study: Cameron Highlands, Malaysia. Journal of the Malaysian Institute of Planners, 15(2), 51-66.

Australian Food and Grocery Council (AFGC). (2014). Market Insights: Malaysia. Retrieved on 23 July 2019 from https://www.appma.com.au/wpcontent/ uploads/2015/02/ afgc03268_malaysia_web_140627.pdf

Misha, S., Mat, S., Ruslan, M.H., Sopian, K. and Salleh E. (2013). Review on the application of tray dryer system for agricultural products. World Applied Sciences Journal, 22(3), 424-433.

Muthukumaran, S., Tranchant, C., Shi, J., Ye, X. and Xue, S.J. (2017). Ellagic acid in strawberry (Fragaria spp.): Biological, technological, stability, and human health aspect. Food Quality and Safety, 1 (4), 227-252. https://doi.org/10.1093/fqsafe/fyx023

Naem, M.N.M., Fairulnizal, M.N.M., Norhayati, M.K., Zaition, A., Norliza, A.H., Syuriahti, W.Z.W., Azerulazree, J.M., Aswir, A.R. and Rusidah, S. 
(2015). The nutritional composition of fruit jams in the Malaysian market. Journal of the Saudi Society of Agriculture Sciences, 16(1), 89-96. https:// doi.org/10.1016/j.jssas.2015.03.002

Nezmer, B., Vargas, L., Xia, X., Sintara, M. and Feng, H. (2018). Phytochemical and physical properties of blueberries, tart cherries, strawberries, and cranberries as affected by different drying methods. Food Chemistry, 262, 242-250. https:// doi.org/10.1016/j.foodchem.2018.04.047

Nicolau-Lapena, I., Abadias, M., Bobo, G., AguilóAguayo, I., Lafarga, T. and Viñas, I. (2019). Strawberry sanitization by peracetic acid washing and its effect on fruit quality. Food Microbiology, 83, 159-166. https://doi.org/10.1016/ j.fm.2019.05.004

Octavia, L. and Choo, W.S. (2017). Folate, ascorbic, anthocyanin and colour changes in strawberry (Fragaria x annanasa) during refrigerated storage. LWT-Food Science and Technology, 86, 652-659. https://doi.org/10.1016/j.lwt.2017.08.049

Osman, A. (2011). Fruits: Nutritious, colourful, yet fragile gifts of nature., p. 55-112. Selangor, Malaysia: Universiti Putra Malaysia Press

Ornelas-Pas, J.J., Yahia, E.M., Ramírez-Bustamante, N., Pérez-Martínez, J.D., Escalante-Minakata, M.P., Ibarra-Junquera, V., Acosta-Muñiz, C., GuerreroPrieto, V. and Ochoa-Reyes, E. (2013). Physical attributes and chemical composition of organic strawberry fruit (Fragaria $x$ ananassa Duch. Cv. Albion) at six stages of ripening. Food Chemistry, 138, 372-381. https://doi.org/10.1016/ j.foodchem.2012.11.006

Rahim, R. and Raman A.A.A. (2015). Cleaner production implementation in a fruit juice production plant. Journal of Cleaner Production, 101, 215-221. https://doi.org/10.1016/j.jclepro.2015.03.065

Rahim, H., Abdul Wahab, M.A.M., Mat Amin, M.Z., Harun, A. and Haimid, M.T. (2016). Economic values of conservation attribute options in Cameron Highlands, Economic and Technology Management Review, 11b(2016), 123-133.

Ramachandran, K., Ishak, N.M. and Ibrahim A.B. (2015). Automated temperature and humidity control system for strawberry plantation using solar panel presented at Proceeding of $36^{\text {th }}$ The International Institute of Engineers and Researchers (IIER) International Conference 2015. Bali, Indonesia: IIER.

Riad, G.S., and Brecht, J.K. (2005). Simulated longdistance transport of strawberries in a passive modified atmosphere marine container. Proceedings of the Florida State Horticultural Society, 118, 396399.

Salami, P., Ahmadi, H., Keyhani, A. and Sarsaifee, M. (2010). Strawberry post-harvest losses in Iran, Researcher, 2(4), 64-73.

Shishehgarha, F., Makhlouf, J. and Ratti, C. (2002) Freeze-drying characteristics of strawberries, Drying Technology, 20(1), 131-145. https://doi.org/10.1081/ DRT-120001370

Sulaiman, A., Farid, M. and Silva F.V.M. (2016) Strawberry puree processed by thermal, high pressure or power ultrasound: process energy requirements and quality modelling during storage. Food Science and Technology International, 23(4), 293-309. https://doi.org/10.1177/1082013216685485

Tengku Mohemed, T.M. (2017). Postharvest and Unsung Solution for Food Security., p. 1-91. Selangor, Malaysia: Penerbit Universiti Putra Malaysia.

Wang, Z., Zhang, M., and Wu, Q. (2015). Effects of temperature, $\mathrm{pH}$, and sunlight exposure on the color stability of strawberry juice during processing and storage. LWT-Food Science and Technology, 60, 1174-1178. https://doi.org/10.1016/j.1wt.2014.09.015

Yang, S., Chen, R., Johnb, S., Ye, J., Fan, G., Zhou, H., Peng, L. and Pana, S. (2018). Physiological and quality changes of postharvest strawberries at different storage temperature and their relationships to fruit discoloration. International Journal of Food and Nutritional Science, 4(2), 81-88.

Zeb, A., Amin, N.U., Shah, S., Ayub, M., Ali Khan, M., Shah, F.N., Ali Z. and Hassan Khan, S. (2015). Postharvest evaluation of strawberry fruit preserves in different concentration of sucrose solution and potash alum stored at ambient temperature. Journal of Nutrition and Food Sciences S13, 1-8. https:// doi.org/10.4172/2155-9600.S13-001 